\title{
Rasio-Rasio Keuangan Sebagai Prediktor Return Saham Pada Perusahaan Manufaktur Yang Terdaftar Di Bursa Efek Indonesia
}

\author{
I Wayan Pradnyantha Wirasedana ${ }^{1}$ \\ Fakultas Ekonomi dan Bisnis \\ Universitas Udayana, Indonesia \\ Email: ochawrs@gmail.com
}

\author{
Putu Ery Setiawan ${ }^{2}$ \\ Fakultas Ekonomi dan Bisnis \\ Universitas Udayana, Indonesia
}

\begin{abstract}
ABSTRAK
Rasio keuangan telah digunakan sejak dulu untuk menilai kinerja keuangan perusahaan dan memprediksi kinerja di masa depan, termasuk return sahamnya. Penelitian bertujuan untuk mengetahui kemampuan prediksi dari berbagai rasio keuangan terhadap return saham. Pengujian statistik dengan SPSS dilakukan terhadap 97 perusahaan manufaktur di BEI selama periode 2009-2016 atau sebanyak 748 data amatan. Pengujian dilakukan dengan melakukan regresi sederhana terhadap masing-masing rasio dan regresi majemuk dengan metode stepwise guna mengidentifikasi rasio-rasio yang mampu memprediksi return saham. Hasil pengujian regresi sederhana terhadap masing-masing rasio menunjukkan bahwa kemampuan prediktif terbesar dimiliki oleh Return on Assets diikuti oleh Assets Turnover, Return on Equity, Debt to Equity Ratio dan Earnings per Share. Pengujian regresi majemuk dengan metode stepwise menunjukkan bahwa kombinasi dari rasio Return on Assets, Debt to Equity Ratio dan Inventory Turnover memberikan kemampuan prediktif terbesar di antara rasio-rasio yang diuji.
\end{abstract}

Kata Kunci: Debt To Equity Ratio; Rasio Keuangan; Return On Assets, Return Saham; Turnover.

Financial Ratios as Predictors of Stock Return in Manufacturing Companies Listed on the Indonesia Stock Exchange

\section{ABSTRACT}

Financial ratios have been used long ago to assess a company's financial performance and predict future performance, including stock returns. The study aims to determine the predictive ability of various financial ratios to stock returns. Statistical testing with SPSS was conducted on 97 manufacturing companies on the Stock Exchange during the period 20092016 or as many as 748 observational data. Testing is done by performing a simple regression of each ratio and multiple regression using the stepwise method to identify ratios that are able to predict stock returns. Simple regression test results on each ratio show that the greatest predictive ability is owned by Return on Assets followed by Assets Turnover, Return on Equity, Debt to Equity Ratio and Earnings per Share. Multiple regression testing using the stepwise method shows that the combination of the ratio of Return on Assets, Debt to Equity Ratio and Inventory Turnover provides the greatest predictive ability among the ratios tested.

Keywords: Debt To Equity Ratio; Financial Ratios; Return On Assets, Stock Returns; Turnover.

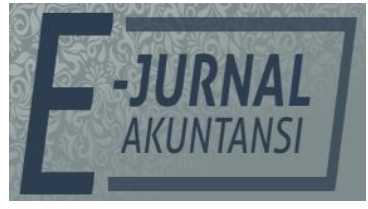

E-JA

e-Jurnal Akuntansi e-ISSN 2302-8556

Vol. 30 No. 6

Denpasar, Juni 2020

Hal.1508-1521

Artikel Masuk: 6 Agustus 2019

Tanggal Diterima: 23 Juni 2020

The Article is Available in: https://ojs.unud.ac.id/index.php/Akuntansi/index 


\section{PENDAHULUAN}

Laporan keuangan yang diterbitkan oleh semua emiten yang terdaftar di Bursa Efek Indonesia ditujukan untuk memberikan gambaran mengenai posisi keuangan dan kinerja keuangan perusahaan. Laporan tersebut ditujukan untuk pihak eksternal dalam membantu pengambilan keputusan, termasuk di dalamnya investor atau calon investor dalam membuat keputusan investasinya. Dari berbagai informasi yang tercantum dalam laporan keuangan, rasio-rasio keuangan kemudian dihitung guna mendapatkan gambaran yang lebih berarti dan dibandingkan antar perusahaan atau dengan rerata industri (Halim, 2019).

Rasio keuangan telah digunakan sejak dulu untuk menilai kinerja keuangan perusahaan dan memprediksi kinerjanya di masa depan. Penggunaan rasio-rasio keuangan oleh para akuntan dan analis keuangan telah dimulai sejak abad ke-19 (Sakemoto, 2017). Rasio-rasio keuangan menjadi begitu umum sehingga selalu melengkapi informasi laporan keuangan suatu perusahaan. Sering pula rasio-rasio tersebut disajikan terpisah tanpa menyajikan data laporan keuangan secara lengkap. Tampaknya rasio keuangan lebih cepat dan praktis untuk dipahami daripada harus membaca laporan keuangan secara terperinci. Dalam perkembangannya, telah banyak pula diciptakan model-model akuntansi dan keuangan mutakhir guna memprediksi return saham seperti model prediksi non-linear, namun rasio-rasio keuangan tetap memiliki tempat tersendiri dalam analisis keuangan dan prediksi saham (Cai \& Gao, 2017).

Para analis pasar modal maupun akademisi telah sejak lama terobsesi guna mengaitkan data-data keuangan terutama rasio-rasio keuangan dengan pergerakan harga saham. Dimulai Kendall \& Hill (1953) yang pada awalnya mencoba mengaitkan pergerakan harga saham dengan harga sebelumnya. Penelitian-penelitian berikutnya berkembang ke arah penggunaan variabelvariabel prediktif seperti dividend yield, price-to-earnings ratio return to equity dan book-to-market value ratio sebagai prediktor harga dan return saham seperti yang dipelopori oleh Ball \& Brown (1968) serta Beaver (1966). Altman (1968) juga memelopori penggunaan rasio-rasio keuangan namun bukan untuk memprediksi return saham, melainkan guna memprediksi kebangkrutan.

Ball \& Brown (1968) memelopori usaha untuk mencari korelasi antara data akuntansi dan harga saham. Dari hasil analisis hubungan antara laba dan harga saham, mereka menemukan bahwa apabila suatu perusahaan memperoleh laba abnormal (excess earnings), maka saham perusahaan tersebut juga akan menghasilkan abnormal return bagi pemegang saham. Beaver (1966) memberikan perspektif lain yang menyatakan bahwa para investor cenderung mendasarkan keputusan trading saham pada informasi akuntansi yang telah diumumkan.

Altman (1968) meneliti tentang kemampuan rasio-rasio keuangan untuk memprediksi kebangkrutan suatu perusahaan. Dalam penelitiannya, ditemukan bahwa rasio-rasio keuangan menunjukkan gejala perubahan yang semakin memburuk mendekati kebangkrutan, terutama antara tahun ketiga dan kedua sebelum kebangkrutan.

Sloan (1996) menguji secara empiris pengaruh laba dan arus kas operasi terhadap harga saham. Penelitiannya menemukan bahwa informasi laba memberikan korelasi yang lebih kuat meskipun tidak secara absolut. Chen \& Zhang (2006) dalam penelitiannya menemukan bahwa arus kas paling 
berpengaruh dalam menentukan harga saham. Wright \& Robbie (1996) meneliti peran informasi akuntansi dalam pengambilan keputusan jual-beli saham oleh investor

Omran \& Ragab (2004) dalam penelitiannya tentang perusahaanperusahaan di Mesir, juga menyimpulkan bahwa selain terdapat hubungan linier antara rasio-rasio keuangan dengan return saham, terdapat pula hubungan yang bersifat non-linier. Miri, et al. (2010) meneliti tentang hubungan linier dan nonlinier antara rasio-rasio keuangan dengan harga saham pada perusahaan industri mineral metalik dan non-metalik. Studi ini menemukan bahwa model nonlinier kuadratik lebih baik dalam menjelaskan pergerakan harga saham dibanding model yang lain.

Arkan (2016) dalam penelitiannya mengenai kemampuan prediktif rasiorasio keuangan terhadap harga saham pada sektor industri, jasa dan investasi di Kuwait menemukan bahwa rasio-rasio Market to Book Value, Return on Equity, Earnings Per Share, Price Earnings, dan Net Profit Margin mampu memprediksi pergerakan harga saham.

Penelitian-penelitian terbaru di Indonesia pun memberikan hasil beragam. Hutabarat \& Simanjuntak (2013) meneliti tentang korelasi antara rasiorasio keuangan dengan harga saham masing-masing perusahaan sektor telekomunikasi di Indonesia dan menemukan bahwa hanya beberapa perusahaan yang menunjukkan korelasi yang kuat antar rasio keuangan dengan harga sahamnya. Handara (2017) yang meneliti 11 perusahaan selama 5 tahun menemukan bahwa rasio Return to Equity, Earnings per Share dan Current Ratio berpengaruh positif pada return saham sementara Debt to Equity ratio berpengaruh negatif. . Lain halnya dengan penelitian oleh Raningsih (2015) yang meneliti 8 perusahaan selama 4 tahun dan menemukan bahwa rasio profitabilitas dan leverage berpengaruh positif pada return saham serta likuiditas berpengaruh negatif.

Banyaknya rasio keuangan yang ada disertai hasil penelitian yang tidak konsisten bukannya membantu pengambilan keputusan bagi investor, melainkan malah membuat investor menghindari penggunaan analisis rasio (fundamental) dalam membuat keputusan investasi. Hal ini terutama terjadi di kalangan investor kecil yang tidak memiliki pemahaman komprehensif mengenai keuangan dan akuntansi. Penelitian ini berusaha mengatasi ketidakkonsistenan tersebut dengan pendekatan yang lebih komprehensif dengan data pengamatan yang lebih besar dan, menggunakan seluruh rasio keuangan yang umum, serta menggunakan model regresi sederhana maupun regresi majemuk dengan metode stepwise. Metode stepwise adalah metode regresi majemuk dimana dari berbagai variable bebas yang dimasukkan dalam model akan disaring menjadi hanya beberapa variable yang memiliki pengaruh signifikan saja yang nantinya muncul dalam hasil regresinya (Arkan, 2016). Kedua pendekatan regresi ini disertai penggunaan rasio dan data yang komprehensif diharapkan dapat mengerucutkan rasio-rasio tersebut menjadi beberapa rasio yang paling penting saja. Hal ini guna mengatasi ketidakkonsistenan hasil penelitian terdahulu dan yang lebih penting lagi dapat membantu investor kecil untuk focus pada beberapa rasio yang terpenting saja. 
Menurut PSAK Nomor 1 (Ikatan Akuntan Indonesia, 2017), tujuan laporan keuangan adalah memberikan informasi mengenai posisi keuangan, kinerja keuangan, dan arus kas entitas yang bermanfaat bagi sebagian besar kalangan pengguna laporan dalam pembuatan keputusan ekonomi. Laporan keuangan ditujukan teurtama untuk pihak investor maupun kreditor guna membantu pengambilan keputusan baik itu keputusan investasi maupun kredit. Dalam perspektif ilmu ekonomi, laporan keuangan berperan penting dalam pengalokasian sumber daya pada kesempatan produksi yang paling efisien. Dalam pasar modal yang efisien, laporan keuangan memegang peran yang sangat penting bagi pengambilan keputusan investor.

Akan sangat sulit untuk membandingkan berbagai angka yang tercantum dalam satu perusahaan dengan perusahaan lainnya. Belum lagi jika kita harus menganalisis sedemikian banyak angka dalam setiap komponen laporan keuangan. Cara yang umum dan praktis yang dilakukan oleh para praktisi adalah dengan menghitung rasio antar berbagai angka keuangan yang kemudian dibandingkan untuk mengetahui nilai relatif saham sebuah perusahaan. Keuntungan utama dari rasio keuangan adalah lebih mudah untuk dipahami dan dapat dibandingkan antar perusahaan karena tidak terpengaruh dengan ukuran perusahaan. Rasio-rasio keuangan digunakan untuk menganalis posisi keuangan seperti likuiditas atau leverage, kinerja operasional seperti profitabilitas atau turnover, dan daya tarik (attractiveness) sebagai instrumen investasi seperti valuasi dan yield (Arkan, 2016).

Secara umum rasio keuangan dapat diartikan sebagai sebuah nilai yang dihasilkan dengan membandingkan dua atau lebih nilai yang bersumber baik dari komponen-komponen neraca, laba rugi, laporan arus kas maupun campuran dari ketiganya. Rasio keuangan dapat dinyatakan dalam persentase, kali (multiples) atau rasio. Dalam perkembangannya, rasio keuangan juga meliputi perbandingan dengan nilai-nilai pasar seperti harga saham, kapitalisasi atau jumlah saham beredar. Karena begitu luas pemakaian dari rasio-rasio keuangan ini dibandingkan dengan data laporan keuangannya itu sendiri, para akademisi telah menelitinya selama hampir satu abad.

Halim (2019) mendefinisikan analisis keuangan sebagai sebuah proses dimana eksplorasi dan derivasi sekelompok indikator kuantitatif dan kualitatif aktivitas ekonomi berkontribusi dalam menentukan signifikansi properti dari sebuah aktivitas operasi dan posisi keuangan, dalam rangka menggunakan indikator-indikator tersebut untuk menilai kinerja perusahaan guna pengambilan keputusan. Sedangkan Humeedat (2018) menyatakan analisis keuangan sebagai sebuah studi terperinci terhadap laporan keuangan dalam rangka untuk mengidentifikasi kekuatan dan kelemahan suatu perusahaan, mendiagnosa permasalahan guna mencari solusi serta mempelajari informasi historis untuk memprediksi masa depan.

Perkembangan analisis keuangan terutama analisis rasio telah menjamah berbagai bidang. Tidak hanya praktisi dunia investasi, analisis rasio juga digunakan oleh bank dalam keputusan pembelian kredit sampai pemerintah dan otoritas jasa keuangan (Halim, 2019). Luasnya cakupan penggunaan rasio keuangan tidak terlepas dari kemudahan perhitungan rasio dan penggunaannya dalam penilaian kinerja tanpa harus melihat data keuangan terperinci, serta 
kemampuannya untuk dibandingkan baik dengan perusahaan lain, rerata industri, atau standar umum lainnya.

Penggunaan analisis rasio dapat disesuaikan dengan kepentingan pemakainya. Analisis rasio yang dilakukan oleh seorang akuntan mungkin berbeda dengan seorang investor retail baik dalam hal cakupan maupun kompleksitasnya. Di sisi lain, seorang analis keuangan profesional yang berkepentingan dengan kinerja perusahaan di masa depan akan menerapkan teknik yang komprehensif dengan menggunakan berbagai rasio dalam upaya memperoleh gambaran tentang hubungan antar komponen-komponen laporan keuangan yang telah diterbitkan (Halim, 2019). Rasio-rasio yang didapat dari suatu perusahaan pada suatu periode tertentu kemudian dibandingkan dengan salah satu dari tiga cara berikut (Arkan, 2016). Perbandingan Cross-Section, terdiri dari Intra-industri: rasio suatu perusahaan dibandingkan dengan perusahaan lain dalam industri yang sama dimana rerata industri menjadi standarnya. Interindustri: rasio suatu perusahaan dibandingkan dengan perusahaan lain dalam industri yang berbeda atau rerata dari industri lain. Pendekatan ini seringkali tidak memberikan hasil komparasi yang baik karena perbedaaan karakteristik dari perusahaan-perusahaan dalam industri yang berbeda. Perbandingan Intertemporal menggunakan cara rasio perusahaan pada periode tertentu dibandingkan dengan periode lain guna identifikasi tren dan hubungan lainnya. Perbandingan dengan Standar Umum menggunakan cara rasio perusahaan dibandingkan dengan standar "tradisional" yang disepakati.

Selain keunggulan-keunggulan tersebut, analisis rasio keuangan juga tidak terlepas dari berbagai kelemahan. Arkan (2016) mengemukakan tiga kelemahan utama dari rasio kuangan. Pertama, analisis rasio keuangan sangat bergantung kualitas laporan keuangan yang diterbitkan perusahaan. Analisis rasio akan mewarisi segala kelemahan dan kekurangan dari laporan keuangan. Kedua, lemahnya daya prediksi. Kebanyakan perilaku masa depan dari suatu variabel, seperti misalnya harga saham, dapat dipengaruhi oleh banyak variabel yang tidak dapat dikendalikan. Ketiga, kelemahan dalam memberikan jawaban. Rasio keuangan tidak mampu memberikan jawaban definitif ya atau tidak, tapi lebih sebagai pengarahan perhatian dan bukan sebagai pemecahan masalah. Banyak informasi tambahan yang perlu dianalisis dibalik nilai rasio-rasio tersebut untuk mendapatkan jawaban menyeluruh.

Informasi yang dapat digali dari laporan keuangan sangatlah beragam sesuai dengan kebutuhan pemakai. Rasio-rasio yang dapat dihitung untuk analisis pun sangat beragam jenisnya, namun secara garis besar dapat dikelompokkan ke dalam rasio likuiditas, profitabilitas, leverage, operasi dan valuasi (Halim, 2019). Adapun rincian dari kelompok-kelompok rasio tersebut dapat dilihat pada Tabel 1 berikut.

Modal dari sebuah perseroan terbatas (PT) terbagi atas saham-saham. Di dunia investasi, saham merupakan instrumen yang paling umum dan aktif diperdagangkan di pasar sekunder. Saham memberikan pemegangnya hak atas pembagian laba dan hak suara dalam pengendalian manajemen dari perusahaan secara proporsional. 
Tabel 1. Kelompok Rasio - rasio Keuangan

\begin{tabular}{|c|c|c|}
\hline Rasio & Formula & Keterangan \\
\hline \multicolumn{3}{|c|}{ Kelompok1: Rasio Likuiditas } \\
\hline $\begin{array}{l}\text { Current Ratio } \\
(\mathrm{CR})\end{array}$ & Aset Lancar: Liabilitas Lancar & $\begin{array}{l}\text { Menunjukkan kemampuan } \\
\text { perusahaan dalam melunasi } \\
\text { kewajiban jangka pendek }\end{array}$ \\
\hline $\begin{array}{l}\text { Quick Ratio } \\
\text { (QR) }\end{array}$ & $\begin{array}{l}\text { (Aset Lancar - Persediaan - } \\
\text { Pembayaran di Muka): } \\
\text { Liabilitas Lancar }\end{array}$ & $\begin{array}{l}\text { Rasio ini berfokus pada sumber } \\
\text { pendanaan jangka pendek } \\
\text { berupa setara kas dan piutang }\end{array}$ \\
\hline \multicolumn{3}{|c|}{ Kelompok 2: Rasio Profitabilitas } \\
\hline $\begin{array}{l}\text { Return On } \\
\text { Assets (ROA) }\end{array}$ & Laba Bersih : Total Aset & $\begin{array}{l}\text { Menunjukkan produktifitas } \\
\text { perusahaan dalam menghasilkan } \\
\text { laba dari aset yang dimiliki }\end{array}$ \\
\hline $\begin{array}{l}\text { Return On } \\
\text { Equity (ROE) }\end{array}$ & Laba Bersih : Total Ekuitas & $\begin{array}{l}\text { Menunjukkan kemampuan } \\
\text { perusahaan dalam menghasilkan } \\
\text { laba dari ekuitas pemegang } \\
\text { saham }\end{array}$ \\
\hline $\begin{array}{l}\text { Gross Profit } \\
\text { Margin (GPM) }\end{array}$ & $\begin{array}{l}\text { (Penjualan- Harga Pokok } \\
\text { Penjualan): Penjualan }\end{array}$ & $\begin{array}{l}\text { Manunjukkan seberapa besar } \\
\text { keuntungan kotor dibandingkan } \\
\text { penjualan }\end{array}$ \\
\hline $\begin{array}{l}\text { Net Profit } \\
\text { Margin (NPM) }\end{array}$ & Laba Bersih : Penjualan & $\begin{array}{l}\text { Manunjukkan seberapa besar } \\
\text { keuntungan bersih dibandingkan } \\
\text { penjualan }\end{array}$ \\
\hline \multicolumn{3}{|c|}{ Kelompok3: Rasio Operasi } \\
\hline $\begin{array}{l}\text { Total Assets } \\
\text { Turnover } \\
\text { (ATO) }\end{array}$ & Penjualan: Total Aset & $\begin{array}{l}\text { Mengukur efisiensi penggunaan } \\
\text { aset secara keseluruhan dalam } \\
\text { menghasilkan penjualan }\end{array}$ \\
\hline $\begin{array}{l}\text { Inventory } \\
\text { Turnover (ITO) }\end{array}$ & $\begin{array}{l}\text { Harga Pokok Penjualan: } \\
\text { Persediaan }\end{array}$ & $\begin{array}{l}\text { Mengukur efisiensi penggunaan } \\
\text { persediaan dalam menghasilkan } \\
\text { penjualan }\end{array}$ \\
\hline $\begin{array}{l}\text { Fixed Assets } \\
\text { Turnover } \\
\text { (FATO) } \\
\text { Kelompok } 4 \text { : Ra }\end{array}$ & Penjualan: Aset Tetap & $\begin{array}{l}\text { Mengukur efisiensi penggunaan } \\
\text { aset tetap dalam menghasilkan } \\
\text { penjualan }\end{array}$ \\
\hline $\begin{array}{l}\text { Debt to Equity } \\
\text { Ratio(DER) }\end{array}$ & Total Liabilitas: Total Ekuitas & $\begin{array}{l}\text { Mengukur struktur permodalan } \\
\text { dengan membandingkanjumlah } \\
\text { utang dan ekuitas }\end{array}$ \\
\hline $\begin{array}{l}\text { Debt to Total } \\
\text { Assets (DOTA) }\end{array}$ & Total Liabilitas : Total Aset & $\begin{array}{l}\text { Mengukur seberapa besar porsi } \\
\text { aset yang dibiayai dengan utang }\end{array}$ \\
\hline $\begin{array}{l}\text { Times Interest } \\
\text { Earned (TIE) }\end{array}$ & EBIT : Beban Bunga & $\begin{array}{l}\text { Menunjukkan kemampuan } \\
\text { menanggung beban bunga dari } \\
\text { laba yang dihasilkan }\end{array}$ \\
\hline \multicolumn{3}{|c|}{ Kelompok5: Rasio Valuasi } \\
\hline $\begin{array}{l}\text { Earning Per } \\
\text { Share(EPS) }\end{array}$ & $\begin{array}{l}\text { Laba Bersih : Jumlah Saham } \\
\text { Beredar }\end{array}$ & $\begin{array}{l}\text { Menunjukkan laba yang tersedia } \\
\text { per lembar saham }\end{array}$ \\
\hline $\begin{array}{l}\text { Price to Book } \\
\text { Value (PBV) }\end{array}$ & $\begin{array}{l}\text { Kapitalisasi Pasar: Total } \\
\text { Ekuitas }\end{array}$ & $\begin{array}{l}\text { Mengukur valuasi pasar } \\
\text { perusahaan relatif dibanding } \\
\text { dengan nilai buku dari ekuitas }\end{array}$ \\
\hline $\begin{array}{l}\text { Price Earnings } \\
\text { Ratio (PER) }\end{array}$ & Harga Saham: EPS & $\begin{array}{l}\text { Menunjukkan premi atas laba } \\
\text { dan ekspektasimasa depan }\end{array}$ \\
\hline
\end{tabular}

Sumber: Halim, 2019 
PSAK Nomor 56 (Ikatan Akuntan Indonesia, 2014) mendefinisikan saham biasa adalah instrument ekuitas yang memiliki hak sisa atas kekayaan (residu) setelah hak instrumen-instrumen ekuitas lainnya. Saham sendiri terbagi atas saham preferen dan saham biasa. Saham preferen biasanya tidak disertai dengan hak suara namun memiliki tingkat klaim yang lebih tinggi dibandingkan saham biasa atas pembagian dividen dan pembagian aset saat likuidasi.

Pergerakan harga saham merupakan sebuah misteri besar bagi praktisi pasar modal, investor maupun akademisi. Begitu banyak peneliti berusaha menggali berbagai faktor penggerak harga saham. Meski konsensus umum yang sudah terbentuk mengenai hubungan antara berbagai variabel dengan pergerakan harga saham, ketidakkonsistenan dan faktor-faktor baru terus tetap muncul. Berbagai faktor umum yang diidentifikasi sebagai penggerak harga saham antara lain nilai buku saham, laba, arus kas, dividen, posisi keuangan, kondisi perekonomian secara umum, rumor bursa, permintaan dan penawaran, dan suku bunga.

Return saham merupakan ukuran kinerja saham. Return saham pada dasarnya terdiri dari capital gain/loss dan dividend yield. Capital gain/loss merupakan selisih harga jual dan beli sedangkan dividen yield menunjukkan jumlah dividen dibandingkan dengan harga saham (Halim, 2019). Dalam penelitian ini rasio-rasio akan digunakan untuk memprediksi return return ekspektasi berdasarkan regresi terhadap return historis (realisasian). Return realisasian diukur sebagai total rate of return, yaitu penjumlahan dari capital gain dan dividend yield.

\section{METODE PENELITIAN}

Penelitian ini dilakukan pada perusahaan manufaktur yang terdaftar di Bursa Efek Indonesia (BEI) selama delapan tahun dari 2009 sampai 2016. Adapun jumlah perusahaan adalah 97 perusahaan dengan keseluruhan 748 data amatan. BEI merupakan salah satu bursa terkuat di Asia selain China dan India, dan merupakan salah satu bursa emerging markets yang menjadi sasaran berbagai investor global. Sektor manufaktur dipilih sebagai sektor paling dominan baik dari sisi jumlah emiten maupun porsi kapitalisasi pasar di BEI. Dengan menggunakan satu sektor saja, diharapkan pula dihasilkan rasio-rasio yang lebih comparable.

Penelitian ini bertujuan untuk mengetahui kemampuan prediksi dari berbagai rasio keuangan terhadap return saham. Pengujian dilakukan dalam dua tahap, yakni pertama dengan regresi sederhana antara masing-masing rasio dengan return saham dan kedua dengan mencari kombinasi optimal dari berbagai rasio melalui regresi majemuk dengan metode stepwise.

Analisis statistik dengan regresi sederhana digunakan untuk menguji hubungan dan kemampuan prediktif dari masing-masing rasio keuangan terhadap return saham, dengan menggunakan SPSS dengan tingkat signifikansi 1, 5 dan 10 persen. Kemudian, guna mendapatkan persamaan yang paling baik dalam memprediksi return saham, disusun persamaan regresi majemuk yang terdiri dari kombinasi rasio-rasio keuangan yang memberikan kemampuan prediksi optimal. Metode stepwise diterapkan dalam regresi majemuk guna menyeleksi variabel-variabel yang berpengaruh signifikan saja, sedangkan 
variabel-variabel yang lain akan dieliminasi. Rasio-rasio keuangan yang digunakan dalam penelitian ini antara lain rasio likuiditas (CR dan $Q R$ ), rasio profitabilitas (ROA dan ROE), rasio operasi (ATO dan ITO), rasio leverage (DER) dan rasio valuasi (PER).

Adapun formula untuk menguji kemampuan prediktif masing-masing rasio adalah sebagai berikut:

Estimasi Return Saham $=\alpha+\beta . C R$

Estimasi Return Saham $=\alpha+\beta \cdot Q R$.

Estimasi Return Saham $=\alpha+\beta \cdot$ ROA

Estimasi Return Saham $=\alpha+\beta \cdot$ ROE

Estimasi Return Saham $=\alpha+\beta$.ATO

Estimasi Return Saham $=\alpha+\beta$.ITO

Estimasi Return Saham $=\alpha+\beta$.DER

Estimasi Return Saham $=\alpha+\beta$.PER

Dimana a merupakan konstanta atau intersep dan $\beta$ merupakan koefisien masing-masing rasio.

\section{HASIL DAN PEMBAHASAN}

Tabel 2 menyajikan prediksi hubungan dari masing-masing rasio keuangan dengan return saham.

Tabel 2. Prediksi Hubungan Antara Rasio Keuangan dengan Return Saham

\begin{tabular}{lc}
\hline Rasio & Prediksi Hubungan \\
\hline Current Ratio & Positif \\
Quick Ratio & Positif \\
Return on Assests & Positif \\
Return on Equity & Positif \\
Assets Turnover & Positif \\
Inventory Turnover & Positif \\
Debt to Equity Ratio & Negatif \\
Earning Per Share & Positif \\
\hline
\end{tabular}

Sumber: Arkan, 2016

Dari Tabel 2, dapat dilihat bahwa semua rasio kecuali DER memiliki hubungan positif dengan return saham. Hal ini dapat dijelaskan karena peningkatan nilai rasio-rasio likuiditas seperti $C R$ dan $Q R$, rasio profitabilitas seperti ROA, ROE, dan EPS serta rasio operasi seperti ATO dan ITO merupakan good news yang direspon positif oleh investor. Sebaliknya jika leverage (DER) mengalami peningkatan, hal ini dipandang sebagai peningkatan risiko perusahaan yang dapat berdampak pada kinerja perusahaan di masa datang.

Dengan menggunakan metode stepwise pada SPSS, dilakukan regresi majemuk atas semua rasio-rasio keuangan terhadap return saham. Metode stepwise ini menyeleksi variabel-variabel bebas yang memiliki pengaruh nyata secara bersama-sama terhadap variabel terikat, sehingga menghasilkan kombinasi dengan koefisien determinasi $\left(\mathrm{R}^{2}\right)$ tertinggi. Adapun model regresi majemuk dengan metode stepwise untuk memperoleh kombinasi dengan kemampuan prediktif optimal rasio-rasio keuangan terhadap return saham adalah sebagai berikut:

Estimasi Return Saham $=\alpha+\beta_{1} \cdot X_{1}+\beta_{2} \cdot X_{2}+\ldots \ldots . .+\beta_{n} \cdot X_{n}$ 
Dimana a merupakan konstanta atau intersep, $\beta_{1}, \beta_{2}$ sampai $\beta_{\mathrm{n}}$ sampai merupakan koefisien rasio-rasio terpilih dan $X_{1}, X_{2}$ sampai $X_{n}$ merupakan variabel rasio-rasio terpilih.

Berdasarkan uraian, rancangan penelitian ini dapat digambarkan seperti pada Gambar 1.

Rasio-Rasio

Keuangan:

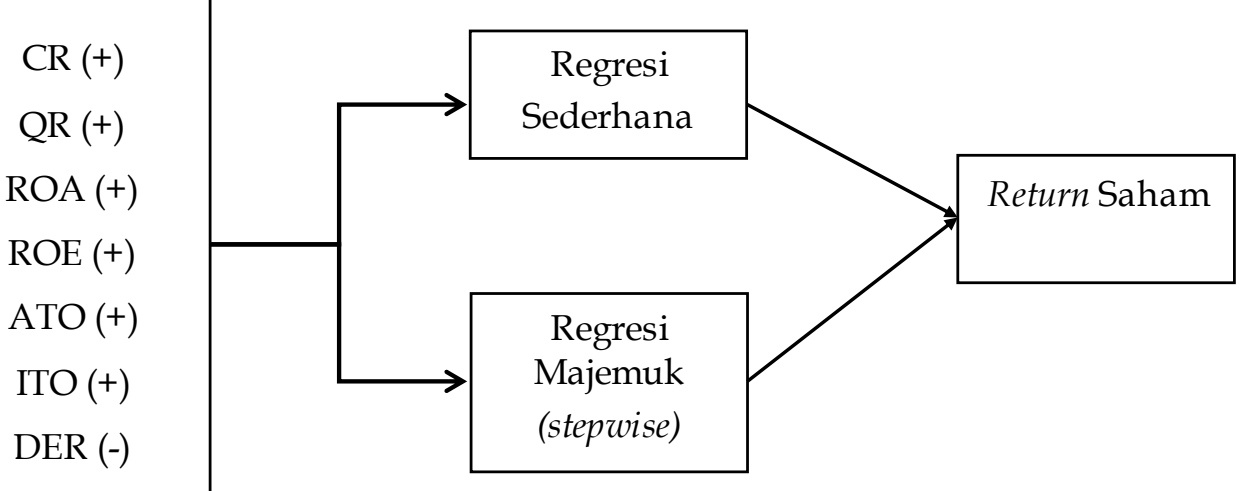

EPS (+)

\section{Gambar 1. Desain Penelitian}

Sumber: Data Penelitian, 2018

Adapun analisis data dilakukan dalam dua tahapan. Pertama-tama dilakukan regresi sederhana untuk setiap variabel rasio untuk melihat pengaruhnya secara individual terhadap return saham. Tabel 3 menyajikan hasil uji statistik terhadap hubungan dari masing-masing rasio keuangan dengan return saham dengan menggunakan persamaan-persamaan regresi sederhana.

Tabel 3. Hasil Uji Statistik Regresi Sederhana antara Rasio Keuangan dan Return Saham Perusahaan Manufaktur

\begin{tabular}{lccc}
\hline \multicolumn{1}{c}{ Rasio } & Prediksi Hubungan & Beta & $\mathrm{R}^{2}$ \\
\hline Current Ratio & Positif & $-0,457$ & 0,00 \\
Quick Ratio & Positif & $-0,098$ & 0,00 \\
Return on Assests & Positif & $1,697^{* *}$ & 0,49 \\
Return on Equity & Positif & $0,382^{* *}$ & 0,19 \\
Assets Turnover & Positif & $23,647^{* *}$ & 0,24 \\
Inventory Turnover & Positif & 1,108 & 0,03 \\
Debt to Equity Ratio & Negatif & $2,039^{*}$ & 0,05 \\
Earning Per Share & Positif & $0,004^{*}$ & 0,04 \\
\hline
\end{tabular}

Keterangan: $\left.{ }^{* *},{ }^{*}\right)$ Signifikan pada $\alpha=5 \%$ dan $10 \%$

Sumber: Data Penelitian, 2018

Dari Tabel 3, diuraikanTidak terdapat hubungan yang signifikan antara Current Ratio, Quick Ratio dan Inventory Turnover dengan return saham. Hal ini dapat terlihat dari nilai signifikansi yang berada 10 persen. Return on Assets, Return on Equity dan Assets Turnover beerpengaruh positif dan signifikan pada a = 5 persen, sedangkan Debt to Equity Ratio dan Earnings per Share signifikan pada $a=10$ persen. Dilihat dari nilai $\mathrm{R}^{2}$, Return on Assets mampu menjelaskan 49 persen dari variasi return saham, sedangkan Return on Equity dan Inventory Turnover mampu menjelaskan masing-masing 19 persen dan 24 persen dari 
variasi return saham. Debt to Equity Ratio berpengaruh positif terhadap return saham pada $a=10$ persen, berlawanan dengan prediksi pengaruh negatif. Sedangkan Earnings Per Share memiliki hubungan positif dengan return saham pada $a=10$ persen. Debt to Equity Ratio dan Earnings Per Share mampu menjelaskan masing-masing 5 persen dan 4 persen dari variasi return saham.

Pengolahan data tahap kedua dilakukan dengan menggunakan metode stepwise pada SPSS, yakni regresi majemuk atas semua rasio-rasio terhadap retum saham. Metode stepwise ini menyeleksi variabel-variabel bebas yang memiliki pengaruh nyata secara bersama-sama terhadap variabel terikat, sehingga menghasilkan kombinasi dengan koefisien determinasi $\left(\mathrm{R}^{2}\right)$ tertinggi. Hasil regresi majemuk dengan metode stepwise disajikan dalam Tabel 4.

Tabel 4. Hasil Uji Statistik Regresi Majemuk dengan Metode Stepwise antara Rasio- Keuangan dan Return Saham Perusahaan Manufaktur

\begin{tabular}{lccc}
\hline \multicolumn{1}{c}{ Rasio } & Prediksi Hubungan & Beta & Signifikansi \\
\hline Konstanta & & 12,722 & 0,022 \\
Return on Assests & Positif & 1,955 & 0,000 \\
Debt to Equity Ratio & Negatif & 3,635 & 0,001 \\
Inventory Turnover & Positif & 1,484 & 0,028 \\
Signifikansi F & & & 0,00 \\
$\mathrm{R}^{2}$ & & & 0,66 \\
\hline
\end{tabular}

Sumber: Data Penelitian, 2018

Dari Tabel 4 dapat dilihat bahwa variabel-variabel rasio yang terpilih adalah Return on Assets, Debt to Equity Ratio dan Inventory Turnover, sedangkan rasio-rasio lain dieliminasi karena menghasilkan pengaruh yang tidak signifikan. Koefisien determinasi menunjukkan bahwa ketiga variabel yang dimasukkan ke dalam model regresi mampu menjelaskan 66\% dari variasi return saham, sedangkan 34\% sisanya dijelaskan oleh faktor lain. Adapun persamaan regresi majemuk yang terbentuk adalah sebagai berikut:

Estimasi Return Saham = 12,722 + 1,955ROA + 3,635DER + 1,484ITO

ROA, DER, maupun ITO kesemuanya berpengaruh positif terhadap return saham. Arah pengaruh ini konsisten dengan hasil regresi sederhana yang dilakukan sebelumnya. Arah pengaruh ROA dan ITO sejalan dengan prediksi awal, sedangkan untuk DER berlawanan dimana prediksi hubungan awal adalah negatif.

Hasil pengujian menunjukkan bahwa beberapa rasio memberikan sinyal positif yang kuat terhadap pergerakan harga saham. Terlihat jelas bahwa baik rasio-rasio profitabilitas (return) maupun rasio-rasio operasi (turnover) dapat diandalkan dalam memprediksi pergerakan harga saham. Selain itu, rasio leverage ikut menunjang peningkatan akurasi apabila digunakan secara bersamasama dengan rasio-rasio lain.

Pengujian kemampuan prediktif masing-masing rasio keuangan terhadap return saham dilakukan untuk mengidentifikasi rasio-rasio mana saja dari seluruh rasio keuangan yang ada yang mampu memprediksi return saham secara handal. Hal ini sangat berguna apabila pengguna laporan keuangan dihadapkan pada begitu banyak rasio yang terkadang sangat membingungkan dan secara historis tidak seluruhnya berkaitan dengan pergerakan harga saham. Investor atau pengguna lain harus bisa memilah dan memilih sehingga mereka 
dapat berfokus pada sedikit rasio yang benar-benar relevan dalam pengambilan keputusan.

Hasil pengujian regresi sederhana terhadap kedelapan rasio dalam penelitian ini mengidentifikasi bahwa rasio profitabilitas seperti ROA dan ROE masih dominan dalam prediksi return saham. Hal ini sejalan dengan penelitian Arkan (2016), yang salah satunya menemukan hubungan kuat antara ROE dan ROE dengan return saham jika dilihat secara terpisah. Hasil penelitian ini sejalan dengan premis bahwa tingkat keuntungan merupakan pertimbangan utama investor dalam memilih saham. Perusahaan-perusahaan dengan tingkat keuntungan yang tinggi akan cenderung lebih diminati oleh investor. Dalam teori investasi, valuasi saham pun sangat ditentukan oleh ekspektasi keuntungan dan arus kas masa depan. Semakin tinggi ekspektasi keuntungan, maka semakin tinggi valuasi terhadap suatu saham.

Selain keuntungan, hasil penelitian ini juga menunjukkan bahwa faktor efisiensi yang tercermin dalam rasio operasi yakni assets turnover terbukti mampu memprediksi return saham. Semakin tinggi tingkat utilisasi aset, maka semakin besar pula pendapatan yang dapat dihasilkan oleh aset yang ada. Hal ini diapresiasi oleh investor sebagai salah satu karakteristik suatu perusahaan yang sehat dan memiliki prospek yang bagus sehingga harga sahamnya pun semakin meningkat.

Analisis mengenai kemampuan prediktif secara simultan dari seperangkat rasio terhadap return saham dilakukan dengan mencoba membentuk kombinasi optimal dari rasio-rasio yang memberikan kemampuan prediktif tertinggi. Hal ini ditujukan untuk memperoleh alat prediksi yang paling akurat terhadap return saham dengan mengkombinasikan beberapa rasio yang ada.

Hasil penelitian menunjukkan bahwa setelah dilakukan regresi majemuk dengan metode stepwise, diperoleh kombinasi rasio optimum yang terdiri dari ROA, DER dan ITO. Hal ini berarti prediksi return saham dengan kombinasi ketiga rasio tersebut akan memberikan tingkat akurasi tertinggi daripada kombinasi-kombinasi lain maupun penggunaan rasio secara terpisah.

ROA terpilih dalam kombinasi rasio optimum sejalan dengan hasil pengujian rasio secara terpisah. Tampaknya ROA lebih unggul daripada ROE dalam kelompok rasio profitabilitas dikarenakan para investor lebih memperhatikan utilisasi aset dalam menghasilkan laba tanpa terdistorsi struktur permodalan perusahaan. ITO pun secara garis besar mengkonfirmasi hasil pengujian rasio secara terpisah dikarenakan ITO sangat erat kaitannya dengan assets turnover. ITO menggarisbawahi komponen utama aset sebagai penghasil laba yakni persediaan. Semakin tinggi perputaran persediaan dalam menghasilkan penjualan, maka semakin baik gambaran efisiensi perusahaan secara keseluruhan dan semakin sehat pula kondisi operasionalnya.

Rasio lain yang tidak kalah penting dalam kombinasi ini adalah leverage (DER). DER menunjukkan dua hal. Di satu sisi DER menunjukkan tingkat risiko keuangan suatu perusahaan, namun di sisi lain DER mampu melipatgandakan keuntungan perusahaan. Pada penelitian ini terlihat DER memberikan pengaruh positif yang berlawanan dengan prediksi awal. Hal ini menunjukkan bahwa para investor lebih memandang DER sebagai alat untuk memaksimalkan keuntungan 
yang tersedia bagi pemegang saham. Hal ini umum terjadi saat optimisme pasar saham sedang tinggi atau tren bullish seperti periode penelitian ini.

Hasil penelitian ini, terutama mengenai rasio ROA dan DER, mendukung penelitian dari Arkan (2016) yang menyebutkan rasio profitabilitas dan leverage merupakan sebagian dari komponen-komponen kombinasi rasio dengan kemampuan prediktif terbaik. Namun sebagai tambahan, penelitian ini juga mengidentifikasi bahwa rasio-rasio operasi (turnover) sangat berpengaruh terhadap return saham. Hasil penelitian ini juga sesuai dengan hasil penelitian Handara (2017) dalam hal rasio profitabilitas yang berpengaruh positif, namun berlawanan dalam hal rasio leverage yang berpengaruh negatif. Penelitian ini juga konsisten dengan penelitian Raningsih (2015) dalam hal profitabilitas dan leverage yang sama-sama berpengaruh positif.

Dari uraian pembahasan dapat dikatakan bahwa hasil penelitian ini semakin memperkuat konsistensi pengaruh positif dari rasio profitabilitas. Namun untuk leverage, diperlukan pemahaman tambahan mengenai kondisi keuangan perusahaan untuk menafsirkan apakah utang yang timbul mencerminkan kondisi perusahaan yang bertumbuh atau tidak. Sebagai tambahan, penelitian ini menunjukkan konsistensi pengaruh rasio operasi (turnover) baik melalui regresi sederhana maupun majemuk sehingga dapat dijadikan pertimbangan yang kuat dalam membuat keputusan.

\section{SIMPULAN}

Dari hasil-hasil dan pembahasan, dapat ditarik beberapa kesimpulan berkaitan dengan hasil analisis regresi sederhana dan regresi majemuk yang dilakukan.

Hasil analisis rasio dengan pendekatan terpisah (regresi sederhana) menunjukkan bahwa rasio yang paling besar kemampuan prediktabilitasnya adalah ROA diikuti oleh ATO, ROE, DER dan EPS. Keseluruhan sifat hubungan mengkonfirmasi prediksi hubungan kecuali untuk DER dimana hasil menunjukkan hubungan positif yang berlawanan dengan prediksi yang negatif.

Hasil analisis rasio dengan mengkombinasikan berbagai rasio terpilih (regresi majemuk dengan metode stepwise) menghasilkan kemampuan prediktif yang lebih tinggi lagi. Model regresi majemuk optimal didapat dengan memasukkan variabel-variabel ROA, DER dan ITO. Arah hubungan masingmasing variabel menunjukkan pengaruh positif, hal ini sejalan dengan prediksi terkecuali untuk DER.

Arah hubungan rasio-rasio keuangan dengan return saham sesuai dengan prediksi dan penelitian-penelitian sebelumnya terkecuali untuk DER. Arah hubungan DER yang positif menunjukkan bahwa peningkatan DER direspon positif oleh pelaku bursa. Salah satu kemungkinan penyebabnya adalah perusahaan-perusahaan manufaktur di BEI kebanyakan dalam tahap pertumbuhan dimana utang yang timbul dipergunakan untuk tujuan-tujuan produktif seperti ekspansi usaha atau belanja modal.

Pihak-pihak yag berkepentingan dengan return dan pergerakan harga saham seperti investor, analis keuangan atau manajemen dapat mengandalkan berbagai rasio dalam melakukan evaluasi kinerja perusahaan dan pengambilan keputusan dengan fokus utama pada rasio-rasio profitabilitas, operasi dan leverage. 
Penelitian ini secara keseluruhan menyimpulkan bahwa para investor dan pihak-pihak lain dapat mengandalkan penggunaan seperangkat rasio keuangan untuk memprediksi pergerakan harga saham. Investor atau pihak lainnya dapat membuat keputusan-keputusan praktis berdasarkan analisis rasio, baik itu keputusan investasi, keuangan maupun operasional.

\section{REFERENSI}

Altman, E. I. (1968). Financial Ratios, Discriminant Analysis and the Prediction of Corporate Bankruptcy. The Journal of Finance, 23(4), 589-609.

Arkan, T. (2016). The Importance of Financial Ratios in Predicting Stock Price Trends: A Case Study in Emerging Markets. Zeszyty Naukowe Uniwersytetu Szczecinskiego Finanse Rynki Finansowe Ubezpieczenia, 1(1), 13-26.

Ball, R., \& Brown, P. (1968). An Empirical Evaluation of Accounting Income Numbers. Journal of Accounting Research, Autumn, 159-178.

Beaver, W. H. (1966). Financial Ratios As Predictors of Failure. Journal of Accounting Research, 4, 71. https://doi.org/10.2307/2490171

Cahyaningrum, N. H. (2012). Analisis Manfaat Rasio Keuangan dalam Memprediksi Pertumbuhan Laba. Skripsi, Fakultas Ekonomi dan Bisnis Universitas Diponegoro.

Cai, B. \& Gao, J. (2017). A Simple Nonlinear Predictive Model for Stock Returns. Working Paper 18/17 November. Department of Economics and Business Statistics Monash Busines School

Chen, P. F., \& Zhang, G. (2006). How Do Accounting Variables Explain Stock Price Movements? Theory and Evidence. In Research Paper (Vol. 07).

Halim, A. (2019). Analisis Investasi,Edisi Ke-2. Jakarta: Salemba Empat.

Handara, IMPDPP. \& Purbawangsa, IBA. (2017). Pengaruh Rasio Keuangan, Kondisi Pasar Modal dan Perubahan Nilai Tukar terhadap Return Saham. E-Jurnal Manajemen Universitas Udayana Vol.6 No.2 hal 663-696.

Humeedat, M. M. (2018). Earnings Management to Avoid Financial Distress and Improve Profitability: Evidence from Jordan. International Business Research, 11(2), 222.

Hutabarat, F., \& Simanjuntak, D. (2013). The Relationship Between Financial Ratios and Stock Prices of Telecommunication Companies of Indonesian Stock Exchange Telecommunication Sub Sector Indices. Jurnal Ekonomi, $4(2)$.

Ikatan Akuntan Indonesia. (2014). PSAK 56 Laba Per Saham.

Ikatan Akuntan Indonesia. (2017). PSAK 1 Penyajian Laporan Keuangan.

Kurniawan, J. (2017). Analisis Kinerja Keuangan Perusahaan Food and Beverage yang Terdaftar di Bursa Efek Indonesia. Skripsi, Fakultas Ekonomi dan Bisnis Islam IAIN Surakarta.

Kendall, M. G., \& Hill, A. B. (1953). The Analysis of Economic Time-Series-Part I: Prices. Journal of the Royal Statistical Society. Series A (General), 116(1), 11. https://doi.org/10.2307/2980947

Miri, S. H., Ebrahimi, S. K., \& Hasan, M. S. (2010, January 1). The Study of Relationship between Financial Ratios and Stock Price in Non Metallic Mine Industries. Financial Accounting Vol. 2, pp. 140-157. 
Ningtyas, C. P., Suhandak \& Nuzula, N.F. (2016). Evaluasi Kinerja dan Perbandingan Analisis Rasio. Jurnal Bisnis dan Manajemen Universitas Udayana Vol.3 No.2 hal. 99-113

Omran, M., \& Ragab, A. (2004). Linear Versus Non-linear Relationships Between Financial Ratios and Stock Returns: Empirical Evidence from Egyptian Firms. Review of Accounting and Finance, 3(2), 84-102.

Raningsih, N. K. \& Putra, IMPD. (2015). Pengaruh Rasio-rasio Keuangan dan Ukuran Perusahaan pada Return Saham. E-Jurnal Akuntansi Universitas Udayana Vol.13 No.2 hal 582-598

Sakemoto, R. (2017). The Nonlinear Dynamic Relationship between Stock Prices and Exchange Rates in Asian Countries. International Journal of Financial Research. Vol 8, No.2 pp. 48-67

Sloan, R. G. (1996). Do Stock Prices Fully Reflect Information in Accruals and Cash Flows about Future Earnings? The Accounting Review. 71(3), 289-315.

Wright, M., \& Robbie, K. (1996). Venture Capitalists, Unquoted Equity Investment Appraisal and the Role of Accounting Information. Accounting and Business Research, 26(2), 153-168. 